\title{
Perceived vulnerability to Coronavirus infection: impact on dental practice
}

\section{María José GONZÁLEZ-OLMO(a) Ana Raquel ORTEGA-MARTíNEZ(b) (D) Bendición DELGADO-RAMOS(c) Martín ROMERO-MAROTO(a) María CARRILLO-DIAZ(a) (D)}

(a) Rey Juan Carlos University, Dentistry Department, Madrid, Spain.

(b)Jaén University, Psychology Department, Jaén, Spain.

(c) Granada University, Dentistry Department, Granada, Spain.

Declaration of Interests: The authors certify that they have no commercial or associative interest that represents a conflict of interest in connection with the manuscript.

\section{Corresponding Author:}

María José González-Olmo

E-mail:mjodont@hotmail.com

https://doi.org/10.1590/1807-3107bor-2020.vol34.0044

Submitted: Mar 28, 2020

Accepted for publication: April 14, 2020

Last revision: Apr 23, 2020
Abstract: SARS-CoV-2 is a new virus responsible for the outbreak of the respiratory disease COVID-19, which has spread to several countries around the world, causing considerable consternation and a fear of contagions in global healthcare settings. The objective of this study is to identify, among Madrid's adult population, the impact of COVID-19 on self-perceived vulnerability, infectiousness, aversion to germs, and other behaviors in the current situation regarding dental practice. This cross-sectional observational study involves 1,008 persons randomly surveyed on the streets of Madrid, Spain between March 1 and March 8, 2020. Their perceived vulnerability to disease was measured using the perceived vulnerability to disease scale. An additional questionnaire evaluated basic sociodemographic aspects, medical history, personal hygiene behavior, willingness to go to certain places and the perception of the risk of contagion when going to a dental practice. There are significant differences by sex on the germ aversion subscale $(p<0.05)$ and in the risk of waiting in the waiting room $(\mathrm{p}<0.01)$, tooth extraction $((\mathrm{p}<0.05)$, endodontics $(\mathrm{p}<0.05)$ and fillings $((\mathrm{p}<0.05)$. Women consider the risk to be higher than men do. The risk group (over 60 and with systemic disease) has significant differences on the subscales of infectivity $(p<0.01)$ and germ aversion $(p<0.01)$. Our study shows high levels of vulnerability regarding contracting COVID-19 and avoiding dental care as perceived by the population over 60 years old and with a systemic disease.

Keywords: Coronavirus Infections; COVID-19, Disease Transmission, Infectious.

\section{Introduction}

SARS-CoV-2 is a new virus responsible for the outbreak of the respiratory disease COVID-19, which has spread to several countries around the world, causing considerable consternation in global health care. On January 30, following the second meeting of the IHR (International Health Regulations) Emergency Committee, the WHO Director-General declared this outbreak a PHEIC (Public Health Emergency of International Concern) because it is a public health risk due its worldwide spread, which requires an internationally coordinated response.

SARS-CoV-2 is a virus in the Coronaviridae family, which is composed of positive-sense single-stranded RNA viruses that have a 
characteristic appearance in negative stain electron microscopy. ${ }^{1}$ COVID-19 produces clinical pictures ranging from the common cold to more serious symptoms, such as those caused by severe acute respiratory syndrome (SARS-CoV) and Middle East respiratory syndrome (MERS-CoV).

This new type of coronavirus appeared in late December of 2019 in Wuhan, China. It is highly infectious in human populations and mainly transmitted via respiratory droplets and physical contact. ${ }^{2}$ Several factors allowed for the rapid spread of this virus: Wuhan is the capital of China's Hubei Province, and it is a major transport hub, increasing person-to-person contact and the possibility of exporting cases to other locations. ${ }^{1}$ In addition, the asymptomatic incubation period for infected persons has been reported as approximately 1-14 days. Patients with a PCR-confirmed COVID-19 infection have had an average age of 55 years (cases in children appear to be rare). ${ }^{3}$ Symptoms of COVID-19 are fever, dry cough, dyspnea, and, in the most severe cases, pneumonia. ${ }^{1,4,5}$ The severity of the disease appears to be associated with age, with elderly populations most at risk; those over 80 years old had a 14.8 percent fatality rate (CFR). ${ }^{6,7}$ The CFR was also higher for those with comorbidities, including cardiovascular disease, diabetes, chronic respiratory disease, hypertension, and cancer. ${ }^{6}$ SARS-CoV-2 will cause many more deaths than its predecessors despite having a mortality rate lower than MERS-CoV infections because there have been many more cases. ${ }^{1}$

Learning how to approach COVID-19 patients for diagnosis and treatment is urgent, as is learning to stop or reduce the number of infections because no specific treatment for the new coronavirus currently exists. However, some antivirals that are being used have shown some effectiveness in recent studies. ${ }^{6,8,9}$ Common transmission routes of the new coronavirus include direct transmission (coughing, sneezing, and transmission by inhaling large or small droplets) and contact transmission (contact with oral, nasal, and ocular mucous membranes). ${ }^{10,11,12,13}$

Mortality is clearly associated with the virus, but the most worrying problem will be a health care system so overwhelmed by the rapid transmission of the virus that affected patients cannot receive necessary care. Patients with other urgent medical conditions are also at risk of not getting necessary care. Countries with vulnerable health care systems are of particular concern.

Through social networks and the media, many people have received alarming news about those infected. This news can negatively affect the population and generate stress, fear of infection, frustration, and inadequate supplies of masks, safety glasses, hand sanitizer, food, and more. Although the new coronavirus mortality rate is between $2 \%$ and $3 \%$, the prevention of a disease can turn into a fear of contagion. This fear of contagion is mainly promoted in places with a large influx of people, such as shopping centers, transportation centers, and gyms, and in spaces where contact with body fluids occurs, such as hospitals, health centers, and dental clinics.

Patients and dental professionals can be exposed to pathogenic microorganisms, including viruses and bacteria, that infect oral cavities and respiratory tracts. ${ }^{12}$ Dental care settings clearly carry the risk of SARS-CoV-2 infection because of their specific procedures, which involve face-to-face communication with patients and frequent exposure to saliva, blood, and other body fluids, as well as handling sharp instruments. ${ }^{12}$ Pathogenic microorganisms can be transmitted in dental environments by inhaling airborne microorganisms that may remain suspended in the air for long periods, ${ }^{14}$ by direct contact with patients' blood or oral fluids; ${ }^{15}$ by contact of the conjunctival, nasal or oral mucosa with droplets and aerosols containing microorganisms generated by an infected individual and propelled at close range by coughing and speaking without the use of a mask, ${ }^{16,17}$ and by indirect contact with contaminated instruments and/or environmental surfaces. ${ }^{18}$

The recent emergence of COVID-19 means that the understanding of its transmission patterns, severity, clinical features, and risk factors for infection remains low, whether among the general population, medical personnel, or families. Therefore, studies to evaluate the general population's vulnerability to the spread of germs and to the current disease are greatly important due to its impact on their daily activity and, more specifically, on dental check-ups or treatment. 
This study aims to identify, among Madrid's adult population, the impact of the current COVID-19 pandemic on self-perceived vulnerability, infectiousness, aversion to germs, and other behaviors that impact dental practice.

\section{Methodology}

\section{Study design and setting}

To address the purpose of this research, the researchers designed and conducted a cross-sectional observational study.

This cross-sectional study involved 1,008 Caucasian participants aged 18 years and older who were randomly surveyed on the streets of Madrid, Spain between March 1 and March 8 of 2020.

The study's participants were between 18 and 83 years old. The participants were $41.50 \%$ male and $58.50 \%$ female. Participants who reported symptoms that could be attributed to an infectious disease at the time of data collection were excluded because this could affect their responses.

All participants were told the purpose of the study, given basic instructions for completing the survey, and informed that all their data would be recorded anonymously. They signed an informed consent statement prior to their inclusion in the study. Our study was approved by the Rey Juan Carlos University Ethics and Research Committee (Registration number: 0103202006520).

\section{Instruments}

The current study used the following self-reported measurements: the perceived vulnerability to disease was assessed via the perceived vulnerability to disease scale validated in Spanish by Magallares et al. ${ }^{19}$ The scores of the participants were obtained by averaging their responses to the items on this scale. Higher scores indicated greater perceived vulnerability to infection. The response format was a seven-point Likert-type scale, ranging from 1 ("Strongly Disagree") to 7 ("Strongly Agree"). This scale has 2 subscales. One captures perceived infectiousness and is assessed by 7 items (e.g., "I am more likely to catch an infectious disease than people in my environment"), and the other captures germ aversion and is assessed by 6 items (e.g., "I prefer to wash my hands right after shaking someone's hand"). The internal consistency (Cronbach's alpha) of these subscales in this study was 0.78 for perceived infectivity and 0.72 for germ aversion.

The participants were also asked about:

a. Basic sociodemographic aspects (gender, age and level of education).

b. Medical history, specifically about the presence of cardiovascular disease, respiratory disease, immunosuppression, or diabetes.

c. Personal hygiene behaviors, such as using a mask or disinfectant and hand washing. The response format was carried out via a dichotomous question (yes/no).

d. The fear of going to the dentist and whether they would cancel an appointment for fear of infection. The response format was carried out via a dichotomous question (yes/no).

e. The perception of risk of contagion when visiting certain places, and the survey asked participants to rate those places according to the risk of coronavirus infection (dental clinic, supermarket, cinema/theater, hospital, sports stadium, gymnasium, nightclub, health center, public toilet, library, and domestic flight). A five-point Likert scale from 1 ("No risk") to 5 ("Very high risk") was used.

$f$. The perception of risk of contagion from going to a dental clinic for certain dental procedures or in certain situations (e.g., being the last patient of the day, waiting in the room for more than 15 minutes, being treated with an extraction, root canal, filling or a scale and polish, or just a simple check-up). A five-point Likert scale from 1 ("No risk") to 5 (“Very high risk") was used.

Statistical analysis was performed using SPSS version 22 (SPSS Inc., Chicago, USA). The data analysis included descriptive statistics and the KolmogorovSmirnov test to evaluate the assumption of normality, which was confirmed. To find possible differences according to gender and the risk group for coronavirus infection (being older than 60 years and having a 
baseline systemic disease), t-tests were performed for quantitative variables and chi-square tests for variables. Previous literature assumes that the elderly population with comorbidities has a higher risk for developing and dying from COVID-19. ${ }^{20}$ Significance levels were established at 0.05 .

\section{Results}

In terms of education levels for the total sample, $12.3 \%$ had completed primary school, $27.7 \%$ had completed secondary school, and $60 \%$ had obtained a university degree.

Regarding systemic diseases, $3.5 \%$ of the subjects had some type of cardiovascular disease, $6.9 \%$ had some type of respiratory disease, $2.6 \%$ were immunosuppressed, and $1.6 \%$ had diabetes.

The $\mathrm{M}$ and SD were 3.29 (1.15) for infectivity subscales and 4.14 (1.19) for germ aversion. Of the sample, $2.3 \%$ used masks on the street, $38.7 \%$ used disinfectant gel, $76.1 \%$ washed their hands when they arrived home, $91.6 \%$ were not afraid of contracting the coronavirus in the dental clinic, and $90.1 \%$ would not cancel a dental appointment for fear of contracting the coronavirus. As seen in Table 1, the average highest risk was for a hospital at 3.38 (1.12), outpatients at 3.26 (1.10), and dental clinics at 3.06 (1.09). For all cases, the risk was medium. For clinical procedures, the most highly perceived risk was being the last patient of the day (Table 2).

Table 1. Mean and standard deviation by risk of contagion in the different spaces.

\begin{tabular}{lc}
\hline Risk variables in space & Mean (DS) \\
\hline Dental clinic & $3.06(1.09)$ \\
Supermarket & $2.61(1.02)$ \\
Cinema & $2,64(1.00)$ \\
Hospital & $3.38(1.12)$ \\
Sports stadium & $2.78(1.08)$ \\
Gym & $2.85(1.10)$ \\
Discotheque & $2.99(1.14)$ \\
Primary health center & $3.26(1.10)$ \\
Public toilet & $2.29(1.04)$ \\
Library & $2.50(.97)$ \\
Domestic flight & $2.95(2.16)$ \\
\hline
\end{tabular}

Table 2. Mean and standard deviation by different dental procedures.

\begin{tabular}{lc}
\hline Dental procedures & Mean (DS) \\
\hline Last patient of day & $2.59(1.17)$ \\
Wait more in the waiting room & $2.34(1.02)$ \\
Dental extraction & $2.11(1.02)$ \\
Dental filling & $2.06(.96)$ \\
Endodontics & $2.11(1.01)$ \\
Dental cleaning & $2.12(.99)$ \\
Routine dental check-up & $2.01(.93)$ \\
\hline
\end{tabular}

\section{Gender differences for the study variables}

No significant differences by gender existed in the infectability subscale, but differences existed in the germ aversion subscale $(p<0.05)$.

No significant differences were found for safety and protection measures, except that hand disinfectant was used $(x 2=11,321, d f=1, p=0.001)$ significantly more by women. No significant differences existed between the genders in the fear of going to the dental clinic or in canceling appointments due to coronavirus infection.

No significant differences existed between the two groups in the risk of visiting any space. However, significant differences appeared in the risk of dental procedures, such as waiting in the waiting room $(p<0.01)$, having a tooth extraction $(p<0.05)$, and having endodontic $(p<0.05)$ and filling procedures $(p<0.05)$. Women considered the risk to be higher than men do for these variables (Table 3).

\section{Differences in the study variables for the risk group}

The sample was separated on the basis of the following risk factors: having at least one underlying systemic disease (cardiovascular disease, respiratory disease, immunosuppression, or diabetes) and being over 60 years old ( 34 subjects).

Significant differences existed in the infectivity $(p<0.01)$ and germ aversion $(p<0.01)$ subscales.

Significant differences were found for safety and protection measures, such as using masks $(\mathrm{x} 2=169,221, \mathrm{df}=1, \mathrm{p}=0.000)$ and disinfectants 
Table 3. Mean, standard deviation and significance according to sex and risk group for the variables of vulnerability to contagion, spaces of contagion and dental procedures.

\begin{tabular}{|c|c|c|c|c|c|c|}
\hline \multirow{3}{*}{ Variables } & Man & Woman & \multirow{3}{*}{$\mathrm{p}$-value } & Risk group & Non-risk group & \multirow{3}{*}{$\mathrm{p}$-value } \\
\hline & $n=418$ & $\mathrm{n}=590$ & & $\mathrm{n}=34$ & $\mathrm{n}=974$ & \\
\hline & $M(S D)$ & $M(S D)$ & & $M(S D)$ & $M(S D)$ & \\
\hline \multicolumn{7}{|l|}{ Vulnerability to infection } \\
\hline Infectability subscale & $3,21(1,20)$ & $3,35(1,10)$ & 0.063 & $5,16(1,05)$ & $3,23(1,09)$ & $0.000^{* *}$ \\
\hline Germ-aversion subscale & $4,05(1,18)$ & $4,21(1,18)$ & $0.036^{*}$ & $5,40(, 70)$ & $4,10(1,17)$ & $0.000^{* *}$ \\
\hline \multicolumn{7}{|c|}{ Risk of contagion in the different spaces } \\
\hline Dental clinic & $2,91(1,09)$ & $3,17(1,08)$ & $0.000^{* *}$ & $3,64(1,06)$ & $3,04(1,09)$ & $0.003^{* *}$ \\
\hline Supermarket & $2,47(1,06)$ & $2,71(, 99)$ & $0.000^{* *}$ & $2,44(, 78)$ & $2,62(1,03)$ & 0.314 \\
\hline Cinema & $2,50(1,02)$ & $2,73(, 98)$ & $0.000^{* *}$ & $2,47(, 86)$ & $2,64(1,01)$ & 0.249 \\
\hline Hospital & $3,23(1,15)$ & $3,49(1,08)$ & $0.000^{* *}$ & $3,85(1,20)$ & $3,37(1,11)$ & $0.028^{*}$ \\
\hline Sports stadium & $2,66(1,10)$ & $2,87(1,05)$ & $0.002^{* *}$ & $2,55(, 74)$ & $2,79(1,09)$ & $0.002^{* *}$ \\
\hline Gym & $2,68(1,14)$ & $2,96(1,05)$ & $0.000^{* *}$ & $3,05(1,09)$ & $2,84(1,09)$ & 0.272 \\
\hline Discotheque & $2,89(1,20)$ & $3,07(1,08)$ & $0.016^{* *}$ & $2,44(, 89)$ & $3,01(1,14)$ & $0.001^{* *}$ \\
\hline Primary health center & $3,09(1,11)$ & $3,38(1,07)$ & $0.000^{* *}$ & $3,82(1,24)$ & $3,24(1,09)$ & $0.011^{*}$ \\
\hline Public toilet & $2,22(1,05)$ & $2,35(1,04)$ & 0.05 & $3,44(1,43)$ & $2,25(1,01)$ & $0.000^{* *}$ \\
\hline Library & $2,37(, 96)$ & $2,59(, 96)$ & $0.000^{* *}$ & $2,29(, 79)$ & $2,51(, 97)$ & 0.129 \\
\hline Domestic flight & $2,72(1,18)$ & $3,10(1,12)$ & $0.000^{* *}$ & $3,47(1,28)$ & $2,93(1,15)$ & $0.021^{*}$ \\
\hline \multicolumn{7}{|l|}{ Dental procedures } \\
\hline Last patient of day & $2,51(1,14)$ & $2,64(1,18)$ & 0.098 & $3,91(1,44)$ & $2,54(1,13)$ & $0.000^{* *}$ \\
\hline Wait more in the waiting room & $2,02(, 99)$ & $2,17(1,04)$ & $0.022^{* *}$ & $3,35(1,53)$ & $2,07(, 97)$ & $0.000^{* *}$ \\
\hline Dental extraction & $1,93(, 92)$ & $2,07(, 94)$ & $0.024^{* *}$ & $2,82(1,05)$ & $1,98(, 92)$ & $0.000^{* *}$ \\
\hline Dental filling & $2,03(1,03)$ & $2,17(, 99)$ & $0.041^{*}$ & $2,94(1,09)$ & $2,08(, 99)$ & $0.000^{* *}$ \\
\hline Endodontics & $2,05(, 98)$ & $2,16(1,00)$ & 0.093 & $2,88(1,03)$ & $2,09(, 98)$ & $0.000^{* *}$ \\
\hline Dental cleaning & $1,99(, 96)$ & $2,11(, 96)$ & .051 & $2,73(, 99)$ & $2,04(, 95)$ & $0.000^{* *}$ \\
\hline
\end{tabular}

${ }^{*} p<0.05 ;{ }^{* *} p<0.01$.

$(\mathrm{x} 2=5,641, \mathrm{df}=1, \mathrm{p}=0.018)$, but no significant differences existed regarding hand washing.

Significant differences existed between groups in the fear of going to the dental clinic due to coronavirus infection $(x 2=128,125, \mathrm{df}=1, \mathrm{p}=0.000)$ and in canceling appointments $(x 2=113,635, d f=1, p=$ 0.000 ), with higher scores in the risk group.

Significant differences existed between both groups for the risk of visiting a dental clinic $(\mathrm{p}<.01)$, a hospital ( $p<.01)$, a nightclub $(\mathrm{p}<0.01)$, a health center $(\mathrm{p}<0.01)$, a sports stadium $(\mathrm{p}<0.01)$, or a public toilet $(p<.01)$, or taking a domestic flight $(p<0.05)$. The risk group shows a higher average than the nonrisk group does for all spaces, except for the nightclub and sports stadium.
For the risk of dental procedures, the risk group shows significantly higher scores than the nonrisk group does for all procedures (Table 3).

\section{Discussion}

In this study, we explored the role of perceived vulnerability to infectiousness and germ aversion in the population, as well as the perception of contracting the coronavirus. Despite global efforts to contain the spread of COVID-19 the outbreak continues to grow due to the pattern of spread of this infection. In Europe, the countries with the most confirmed cases are Italy, Spain, Germany and France. In recent days, a significant increase 
in cases has been reported internationally in Iran, South Korea and the United States.

The coronavirus pandemic in Spain reached its first critical point on the $9^{\text {th }}$ of March, with the number of infected cases doubling in 24 hours. On March 14, the government took strong measures to contain the disease and declared a state of emergency in order to slow down the rate of infection. When the survey was carried out (from the $1^{\text {st }}$ to the $8^{\text {th }}$ of March), there were 1,024 confirmed cases in Spain, compared to 39,673 at the time of writing and this situation is reflected in our results. Only the population at risk (over 60 years of age) perceived the dental clinic as a high risk area for possible contagion, and therefore, only this risk group acted accordingly, avoiding dental services. The results of the study emphasize that, when the survey was conducted, the remaining population did not present high levels of perception of infectivity and germ aversion, without having modified their daily activities (including their dental treatments and check-ups). This attitude contributed to the rapid spread of the disease. Due to the unique characteristics of dental procedures, where a large number of drops and aerosols can be generated, and the close proximity of the working area, the standard protective measures routinely used in a dental practice (surgical mask, gloves, protective nonwaterproof eyewear and a nonwaterproof gown) are not sufficient to prevent the spread of COVID-19, especially when patients are in the incubation period as they do not know that they are infected or choose to hide their infection. ${ }^{21,22,23}$

This research shows that a high percentage of the population followed the prevention protocol recommended by health authorities; $76.1 \%$ washed their hands when they arrived home and 38.7\% used hand sanitizer. Despite this, the number of cases has been increasing; a significant percentage of infected people (approximately 14\%) are health professionals. On March 15, the New York Times published an article entitled "Workers at Highest Risk of Coronavirus", where an impressive schematic figure described that dentists are the workers most at risk of being affected by COVID-19, much more than nurses and general practitioners. ${ }^{24,25}$ Already at the beginning in Wuhan, of the 44,672 initial cases, 3,019
(6.75\%) were health workers. A recent clinical study indicated that $29 \%$ of the 138 hospitalized patients with COVID-19-infected pneumonia in Wuhan were healthcare workers. ${ }^{5}$ With increased public awareness and the uniform adoption of personal protective equipment, the risk has progressively decreased in Hubei Province. ${ }^{22}$ Dental professionals are particularly at risk if they work on an infected patient due to close contact and the risk of exposure to blood, saliva and droplets.

This study shows significant differences in germ aversion, with the figures being higher in women than in men. This finding is consistent with previous results obtained in the literature. ${ }^{26,27}$ This can be justified by the emotional characteristics involved in the perception of a situation of uncertainty since the literature supports that women, in general, have a greater aversion to risk than men, although this question is not sufficiently studied.

This study also contributes to the understanding of why people over 60 with a systemic pathology would not go to the dentist; it is because they believe that it is easier to contract the coronavirus, especially when you are the last patient of the day, if you are late and must wait for more than 15 minutes, or before treatments, such as a dental extraction, a root canal or a filling.

It is also important to recognize some limitations in this study. First, the representativeness of our sample of convenience may be questioned. However, the gender of the participants was reasonably balanced among the subjects, and the prevalence of vulnerability to infectivity and aversion to germs found in the sample was within the range identified in previous studies carried out in the adult population. ${ }^{26}$

A possible second limitation comes from the use of self-report measures, which can be affected by responses based on social desirability. Third, the timing of the study and its cross-sectional design have reflected a very specific moment in time when the disease began to spread. Despite this, the information obtained is very valuable given the well-known dramatic situation that was happening in our neighboring country, Italy. The vulnerabilities of the populations, in general, were similar; therefore, the disease could lead to very 
similar results in Spain as far as the seriousness of the spread is concerned, increasing the numbers of infections and deaths. ${ }^{28}$

This research has some relevant implications for dental practice. During the period of data collection, cases and fatalities due to COVID-19 had already been detected in Spain. Despite this detection, the study shows how the population stated that they would not modify their activities related to the dental clinic. Furthermore, during this time, the health authorities did not report any restrictions on dental activity. ${ }^{29,30}$ These two factors, together with the lack of personal protective equipment reported by the Council of Dentists, have contributed to the spread of the virus. ${ }^{31,32}$

On $16^{\text {th }}$ March 2020, the General Council of Dentists recommended that dentists postpone elective procedures for the next five weeks ${ }^{33}$, which could be extended depending on the evolution of the pandemic, and recommended that they only provide treatment for dental emergencies. ${ }^{34,35}$ This fact, together with the shortage of personal protective equipment, has forced the closure of most dental clinics ${ }^{36,37}$, leading to an interruption of oral treatment with the consequent deterioration of the population's oral health and a high economic impact on this sector. ${ }^{31,38}$

Future lines of research will be required, at the end of the pandemic, to confirm the real impact on the oral health of the population and the economic effect on dental clinics.

\section{Conclusion}

In conclusion, this study shows the high levels of vulnerability to contracting COVID-19 as perceived by the population over 60 years of age with a baseline disease at the beginning of the epidemic in Spain and their avoidance of dental care. The results differ for the remaining population, which presents low levels of vulnerability to contracting COVID-19.

\section{Acknowledgments}

The authors thank the study participants for their contribution.

\section{References}

1. Guarner J. Three emerging coronaviruses in two decades. Am J Clin Pathol. 2020 Mar;153(4):420-1. https://doi.org/10.1093/ajcp/aqaa029

2. Li Q, Guan X, Wu P, Wang X, Zhou L, Tong Y, et al. Early transmission dynamics in wuhan, china, of novel coronavirus-infected pneumonia. N Engl J Med. 2020 Mar;382(13):1199-207. https://doi.org/10.1056/NEJMoa2001316

3. Chen N, Zhou M, Dong X, Qu J, Gong F, Han Y, et al. Epidemiological and clinical characteristics of 99 cases of 2019 novel coronavirus pneumonia in Wuhan, China: a descriptive study. Lancet. 2020 Feb;395(10223):507-13. https://doi.org/10.1016/S0140-6736(20)30211-7

4. Huang C, Wang Y, Li X, Ren L, Zhao J, Hu Y, et al. Clinical features of patients infected with 2019 novel coronavirus in Wuhan, China. Lancet. 2020 Feb;395(10223):497-506. https://doi.org/10.1016/S0140-6736(20)30183-5

5. Wang D, Hu B, Hu C, Zhu F, Liu X, Zhang J, et al. Clinical characteristics of 138 hospitalized patients with 2019 novel coronavirusinfected pneumonia in Wuhan, China. JAMA. 2020 Feb;323(11):1061. https://doi.org/10.1001/jama.2020.1585

6. Fisher D, Heymann D. Q\&A: the novel coronavirus outbreak causing COVID-19. BMC Med. 2020 Feb;18(1):57. https://doi.org/10.1186/s12916-020-01533-w

7. Chan JF, Yuan S, Kok KH, To KK, Chu H, Yang J, et al. A familial cluster of pneumonia associated with the 2019 novel coronavirus indicating person-to-person transmission: a study of a family cluster. Lancet. 2020 Feb;395(10223):514-23. https://doi.org/10.1016/S0140-6736(20)30154-9

8. Stockman LJ, Bellamy R, Garner P. SARS: systematic review of treatment effects. PLoS Med. 2006 Sep;3(9):e343. https://doi.org/10.1371/journal.pmed.0030343

9. Li G, De Clercq E. Therapeutic options for the 2019 novel coronavirus (2019-nCoV). Nat Rev Drug Discov. 2020 Mar;19(3):149-50. https://doi.org/10.1038/d41573-020-00016-0

10. Belser JA, Rota PA, Tumpey TM. Ocular tropism of respiratory viruses. Microbiol Mol Biol Rev. 2013 Mar;77(1):144-56. https://doi.org/10.1128/MMBR.00058-12 
- Perceived vulnerability to Coronavirus infection: impact on dental practice

11. Lu CW, Liu XF, Jia ZF. 2019-nCoV transmission through the ocular surface must not be ignored. Lancet. 2020 Feb;395(10224):e39.

12. Peng $X, X \cup X$, Li Y, Cheng L, Zhou X, Ren B. Transmission routes of 2019-nCoV and controls in dental practice. Int J Oral Sci. 2020 Mar;12(1):9. https://doi.org/10.1038/s41368-020-0075-9

13. To KK, Tsang OT, Chik-Yan Yip C, Chan KH, Wu TC, Chan JM, et al. Consistent detection of 2019 novel coronavirus in saliva. Clin Infect Dis. 2020 Feb;12:149. https://doi.org/10.1093/cid/ciaal49

14. Kampf G, Todt D, Pfaender S, Steinmann E. Persistence of coronaviruses on inanimate surfaces and their inactivation with biocidal agents. J Hosp Infect. 2020 Mar;104(3):246-51. https://doi.org/10.1016/i.jhin.2020.01.022

15. Chen J. Pathogenicity and transmissibility of 2019-nCoV-A quick overview and comparison with other emerging viruses. Microbes Infect. 2020 Mar;22(2):69-71. https://doi.org/10.1016/i.micinf.2020.01.004

16. Harrel SK, Molinari J. Aerosols and splatter in dentistry: a brief review of the literature and infection control implications. J Am Dent Assoc. 2004 Apr;135(4):429-37. https://doi.org/10.14219/jada.archive.2004.0207

17. Cleveland JL, Gray SK, Harte JA, Robison VA, Moorman AC, Gooch BF. Transmission of blood-borne pathogens in US dental health care settings: 2016 update. J Am Dent Assoc. 2016 Sep;147(9):729-38. https://doi.org/10.1016/i.adaj.2016.03.020

18. Liu L, Wei Q, Alvarez X, Wang H, Du Y, Zhu H, et al. Epithelial cells lining salivary gland ducts are early target cells of severe acute respiratory syndrome coronavirus infection in the upper respiratory tracts of rhesus macaques. J Virol. 2011 Apr;85(8):4025-30. https://doi.org/10.1128/JVI.02292-10

19. Magallares A, Fuster-Ruiz MJ, Morales JF. Psychometric properties and criterion validity of the perceived vulnerability to disease scale (PVD) in the spanish population. Rev Psicol Soc. 2017;32(1):164-95. Spanish. https://doi.org/10.1080/02134748.2016.1248025

20. Saghazadeh A, Rezaei N. Immune-epidemiological parameters of the novel coronavirus - a perspective. Expert Rev Clin Immunol. 2020 Apr;6:1-6. https://doi.org/10.1080/1744666X.2020.1750954

21. Meng L, Hua F, Bian Z. Coronavirus disease 2019 (covid-19): emerging and future challenges for dental and oral medicine. J Dent Res. 2020 May;99(5):481-7. https://doi.org/10.1177/0022034520914246

22. Sabino-Silva R, Jardim AC, Siqueira WL. Coronavirus COVID-19 impacts to dentistry and potential salivary diagnosis. Clin Oral Investig. 2020 Apr;24(4):1619-21. https://doi.org/10.1007/s00784-020-03248-x

23. Ather A, Patel B, Ruparel NB, Diogenes A, Hargreaves KM. Coronavirus disease 19 (covid-19): implications for clinical dental care. J Endod. Forthcoming 2020 Apr;S0099-2399(20)30159-X. https://doi.org/10.1016/i.joen.2020.03.008

24. Spagnuolo G, De Vito D, Rengo S, Tatullo M. Covid-19 outbreak: an overview on dentistry. Int J Environ Res Public Health. 2020 Mar;17(6):2094. https://doi.org/10.3390/ijerph17062094

25. Gamio L. The workers who face the greatest coronavirus risk. Times Plain Engl. 2020 [cited 2020 Mar 15]. Available from: https://www.nytimes.com/interactive/2020/03/15/business/economy/coronavirus-workerrisk.html?action=click\&module=top + stories\&p gtype $=$ homepage

26. Duncan LA, Schaller M, Park JH. Perceived vulnerability to disease: development and validation of a 15 -item self-report instrument. Pers Individ Dif. 2009;47(6):541-6. https://doi.org/10.1016/i.paid.2009.05.001

27. Fogel J, Chawla GS. Susceptibility, likelihood to be diagnosed, worry and fear for contracting Lyme disease. J Infect Public Health. 2017 Jan - Feb;10(1):64-75. https://doi.org/10.1016/i.jiph.2016.02.011

28. Stevens H. Why outbreaks like coronavirus spread exponentially, and how to "flatten the curve". Washington Post, 2020 mar 14 [cited 2020 March 14]. Available from: https://www.washingtonpost.com/graphics/2020/world/corona-simulator/?itid=hp_hp-top-table-main_ virus-simulator520 pm\%3ahomepage $\% 2$ fstory-ans

29. Consejo Dentistas. Informacion coronavirus. 2020 [cited 2020 Mar 17]. Available from: https://www.consejodentistas.es/comunicacion/ actualidad-consejo/notas-de-prensa-consejo/item/1725-informacion-coronavirus.html

30. Consejo Dentistas. El consejo general de dentistas ofrece a los colegiados información especifica sobre el coronavirus. 2020 mar 11 [cited 2020 Mar 17]. Available from:https://www.consejodentistas.es/comunicacion/actualidad-consejo/notas-de-prensa-consejo/ item/1726-el-consejo-general-de-dentistas-ofrece-a-los-colegiados-informacion-especifica-sobre-el-coronavirus.html

31. Consejo Dentistas. El consejo general de dentistas pide al gobierno protección sanitaria y laboral para los colegiados y sus-empleados. 2020 abr 6 [cited 2020 Mar 17]. Available from: https://www.consejodentistas.es/comunicacion/actualidad-consejo/notas-de-prensaconsejo/item/1759-el-consejo-general-de-dentistas-pide-al-gobierno-proteccion-sanitaria-y-laboral-para-los-colegiados-y-susempleados.html

32. Consejo Dentistas. Los dentistas ponen de manifiesto su solidaridad donando a la sanidad Española sus epis. 2020 mar 20 [cited 2020 Mar 17]. Available from: https://www.consejodentistas.es/comunicacion/actualidad-consejo/notas-de-prensa-consejo/item/1740-losdentistas-ponen-de-manifiesto-su-solidaridad-donando-a-la-sanidad-espanola-sus-epis.html

33. Consejo Dentistas. Se declara el Estado de Alarma en España para frenar la expansion del coronavirus. 2020 mar 14 [cited 2020 Mar 17]. Available from: https://www.consejodentistas.es/comunicacion/actualidad-consejo/notas-de-prensa-consejo/item/1732-se-declarael-estado-de-alarma-en-espana-para-frenar-la-expansion-del-coronavirus.html 
34. Consejo Dentistas El Consejo General de Dentistas DE España pide a los colegiados "responsabilidad" ante la situación sanitaria. 2020 mar 13 [cited 2020 Mar 17]. Available from: https://www.consejodentistas.es/comunicacion/actualidad-consejo/notas-de-prensaconsejo/item/1728-el-consejo-general-de-dentistas-de-espana-pide-a-los-colegiados-responsabilidad-ante-la-situacion-sanitariaactual.html

35. Consejo Dentistas. Recomendaciones de buenas practicas para la atención de urgencias. 2020 [cited 2020 Mar 17]. Available from: https://www.consejodentistas.es/comunicacion/actualidad-consejo/notas-de-prensa-consejo/item/1739-recomendaciones-de-buenaspracticas-para-la-atencion-de-urgencias.html

36. Consejo Dentistas El Consejo General de Dentistas pide al Gobierno que decrete la suspensión temporal de la apertura de clínicas dentales. 2020 mar 19 [cited 2020 Mar 17]. Available from: https://www.consejodentistas.es/comunicacion/actualidad-consejo/notasde-prensa-consejo/item/1738-el-consejo-general-de-dentistas-pide-al-gobierno-que-decrete-la-suspension-temporal-de-la-aperturade-clinicas-dentales.html

37. Consejo Dentistas Comunicado de los Consejos Generales de Dentistas, Enfermeros, Farmacéuticos, Médicos y Veterinarios ante la pandemia del COVID-19. 2020 [cited 2020 Mar 17]. Available from: https://www.consejodentistas.es/comunicacion/actualidadconsejo/notas-de-prensa-consejo/item/1758-comunicado-de-los-consejos-generales-de-dentistas-enfermeros-farmaceuticos-medicos-yveterinarios-ante-la-pandemia-del-covid-19.html

38. Consejo Dentistas Los dentistas reclaman al Gobierno decisiones claras y concretas sobre las medidas laborales a las que pueden acogerse. 2020 abr 7 [cited 2020 Mar 17]. Available from: https://www.consejodentistas.es/comunicacion/actualidad-consejo/notasde-prensa-consejo/item/1760-los-dentistas-reclaman-al-gobierno-decisiones-claras-y-concretas-sobre-las-medidas-laborales-a-lasque-pueden-acogerse.html 